原著

\title{
自己免疫性てんかんにおける診断アルゴリズムの提唱と その有用性の予備的検討
}

\author{
坂本 光弘 ${ }^{1)}$ 松本 理器 ${ }^{1)}$ * 十川 純平 ${ }^{122}$ 端 祐一郎 ${ }^{13)}$ 武山 博文 ${ }^{4)}$ \\ 小林 勝哉 ${ }^{1)}$ 下竹 昭寛 ${ }^{5)}$ 近藤 誉之 ${ }^{3)}$ 高橋 良輔 ${ }^{1)}$ 池田 昭夫 ${ }^{5)}$
}

\begin{abstract}
要旨：自己免疫性てんかんが近年注目されているが，抗神経抗体以外の特異的な診断法は確立していない，今 回我々は最初に病歴・臨床症候, 次に検査成績と 2 段階で自己免疫性てんかんを診断するアルゴリズムを作成し, 臨床的有用性を予備的に検討した．自己免疫性てんかんが疑われた 70 名に後方視的にアルゴリズムを適応した MRI，䯣液，FDG-PET 検査のうち，2 項目以上異常所見があれば診断に近づく可能性が示された．一方で抗体陽 性 13 名のうち 2 名は, 第一段階の臨床症候で自己免疫性てんかんの可能性は低いと判断された. 包括的抗体検査 のもと診断アルゴリズムの更なる検証，改訂が望まれる.
\end{abstract}

（臨床神経 2018;58:609-616）

Key words：自己免疫性脳炎,てんかん，早期診断，アルゴリズム

前文

1980 年代から $\mathrm{Hu}$ 抗体 ${ }^{1) ~ 3)}$ や抗 glutamic acid decarboxylase (GAD）抗体 ${ }^{4}$ にに代表される細胞内抗原を標的とする神経抗 体が傍腫瘍性神経症候群やその他の脳炎，脳症に関連するこ とが知られていた.また 2000 年代以降の抗体検出技術の向上 により，細胞表面抗原に対する様々な特異的神経抗体が発見 され ${ }^{5 / 6)}$ ，それらが関与した自己免疫性脳炎が報告された。症 状として記銘力障害, 精神症状, てんかん発作，自律神経障 害や不随意運動がみられることが多く7)，難治性てんかんの 病態にもこれらの抗体が関与する可能性が示されてきた ${ }^{899}$. 抗体陽性の患者群で抗てんかん薬による治療に抵抗性でも免 疫療法が奏功すること ${ }^{10)}$ ，そして発症から免疫治療開始まで の期間が短いと治療反応性が高いことが報告されている ${ }^{11)}$. これらの報告から, 自己免疫機序が想定されるてんかんでは, 早期の診断・治療介入が重要と示唆される ${ }^{12)}$.

21 世紀初頭には既に自己免疫機序の関与するてんかん症 候群（自己免疫性てんかん）の存在が提唱され ${ }^{13)}$ ，国際抗て んかん連盟（ILAE）の新てんかん症候群分類（2017）ではて んかんの病因の一つとして「免疫」が初めて採用された ${ }^{14)}$.
確定診断には抗神経抗体の測定が望ましいが，現在本邦では 抗神経抗体の測定に時間を要し，早期の診断が難しい。抗神 経抗体を除き, 自己免疫性てんかんの診断に特異的な検査法 は未だ確立していない ${ }^{15)}$. また既知の抗神経抗体が陰性で あっても, 未知の抗神経抗体の関与が想定される自己免疫 性てんかんの症例も存在しうる。近年診断向上に向けて, Toledano らは「自己免疫性てんかんを示唆する臨床的特徴」 を提唱し ${ }^{11)}$ ，Graus らは自己抗体の検査を参考としない自己 免疫性辺縁系脳炎の診断基準案を発表した ${ }^{16)}$ ，両者には「急 性あるいは亜急性の経過」「髄液所見の異常」「Magnetic Resonance Imaging (MRI) での内側側頭葉の異常」という共 通点がみられ，Toledano らは「自己免疫疾患の既往」「悪性疾 患の既往」「ウイルスの先行感染」「fluorodeoxy glucose - positron emission tomography（FDG-PET）での代謝充進」を診断に有 用な所見として挙げており，Grausらは「記銘力障害」「精神 症状」など辺縁系の異常を示唆する臨床症状や「両側側頭部 の脳波の異常所見」を挙げている，今回我々は Toledanoら ${ }^{11)}$ の提唱する「自己免疫性てんかんを示唆する臨床的特徴」の 各項目を参考に, 病歴・臨床症状から諸検査を行うという実 臨床での流れを考慮した診断アルゴリズムを作成した。当院

\footnotetext{
*Corresponding author: 京都大学大学院医学研究科臨床神経学〔邓 606-8507 京都市左京区聖護院川原町 54〕

1) 京都大学大学院医学研究科臨床神経学

2) 独立行政法人国立病院機構京都医療センター神経内科

3) 関西医科大学総合医療センター神経内科

4) 京都大学大学院医学研究科呼吸管理睡眠制御学

5) 京都大学大学院医学研究科てんかん・運動異常生理学

(Received April 18, 2018; Accepted August 16, 2018; Published online in J-STAGE on September 29, 2018)

doi: 10.5692/clinicalneurol.cn-001180
} 
で自己免疫性てんかんが疑われた患者群に後方視的にアルゴ リズムを適応した。抗神経抗体陽性群を自己免疫性てんかん の確診例として，抗神経抗体陰性群との比較により，本アル ゴリズムの自己免疫性てんかんの診断における有用性を検証 した.

\section{対象・方法}

2012 年 1 月以降にてんかん発作あるいはその疑いで当院神 経内科外来を受診し, 関連する診療情報 (治療抵抗性, 脳 MRI 異常所見, 髄液異常所見, FDG-PET での代謝克進部位の存 在など）の組み合わせからてんかん専門医が自己免疫機序の 関与を疑い入院精査を行った 111 例を対象とした。 そのうち, 腫瘍, 血管障害などの自己免疫以外の明確な原因が存在せず, また抗 voltage-gated potassium channels (VGKC) 複合体抗体, 抗 GAD 抗体，抗 N-methyl-D-aspartate（NMDA）受容体抗体 のいずれかを測定した 70 例について, 後方視的にアルゴリズ ムを適応した。尚, 本研究は京都大学大学院医学研究科・医 学部及び医学部附属病院医の倫理委員会の承認を 2011 年 12 月 26 日に得ている（承認番号 C-0588-4）.

アルゴリズム（Fig. 1）では，病歴 / 臨床症状，抗神経抗体 の有無，各種検査所見の 3 段階に分けて患者を分類した。第 1 段階の病歴 / 臨床症状では,
・「適切な薬物療法に抵抗性」で「難治性でかつ急性あるい は亜急性の経過」をとる

あるいは

・特徵的な臨床像として,「発作型が多彩/faciobrachial dystonic seizures (FBDS $)^{17)} 」 \Gamma$ 自己免疫疾患の既往ないし家族歴」 「悪性腫瘍の既往」「ウイルスの先行感染」のいずれかを満 たす

かどうかを検討した。いずれかの条件を満たした患者群は， 病歴 / 臨床症状から考えて自己免疫性てんかんの可能性が高 く，追加検査を要すると判断しアルゴリズム第 2 段階に進み， 一方，満たさない群はアルゴリズム第 1 段階で自己免疫性て んかんの可能性が低い群（F 群）に分類した。

第 2 段階の抗神経抗体検査では，抗神経抗体陽性例を A 群 とした

抗体陰性患者は，最後の第 3 段階に進み，各種検査，すな わち

(1)「髄液異常所見」(細胞数 $>5 / \mu l$, 髄液蛋白 $>40 \mathrm{mg} / \mathrm{d} l$, 才 リゴクローナルバンド (oligoclonal bands; OCB）陽性),

(2)「脳 MRI 異常所見」(内側側頭葉ないし脳実質の fluid attenuated inversion recovery（FLAIR）法での高信号病変, あるいは扁桃体腫大),

(3)「FDG-PET での局所性の代謝忘進の有無」 から，3 項目とも満たす群を B 群，2 項目のものを C 群，1 項

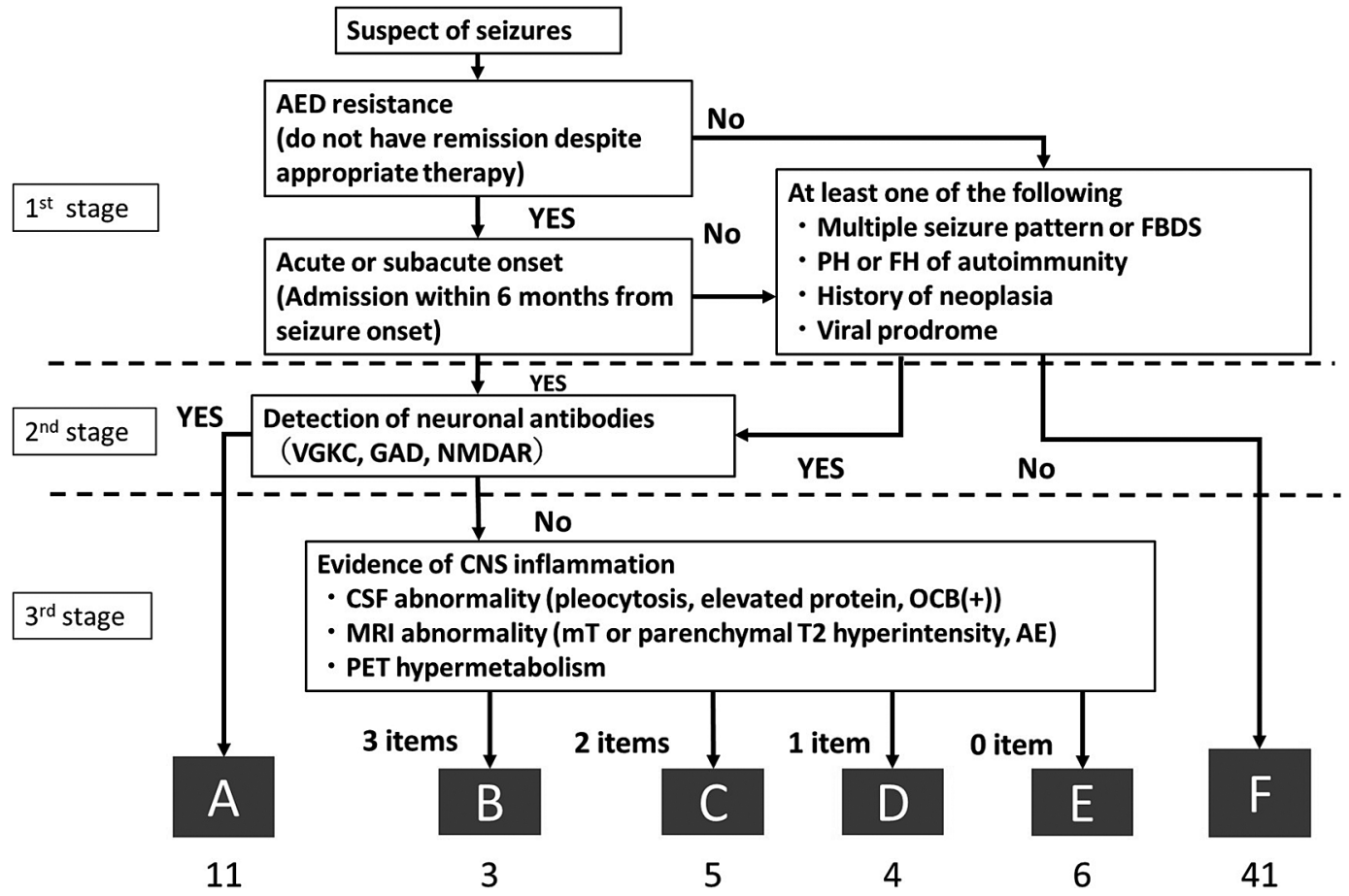

Fig. 1 Algorithm for diagnosis of autoimmune epilepsy (proposal).

The numbers listed under each category represent the number of patients classified into their respective categories. AED: antiepileptic drugs, CSF: cerebrospinal fluid, FBDS: faciobrachial dystonic seizure, VGKC: voltage-gated potassium channels, GAD: glutamic acid decarboxylase, NMDAR: N-methyl-D-aspartate receptor, PH: past history, FH: family history, CNS: central nervous system, OCB: oligoclonal bands, mT: medial temporal, AE: amygdala enlargement. 


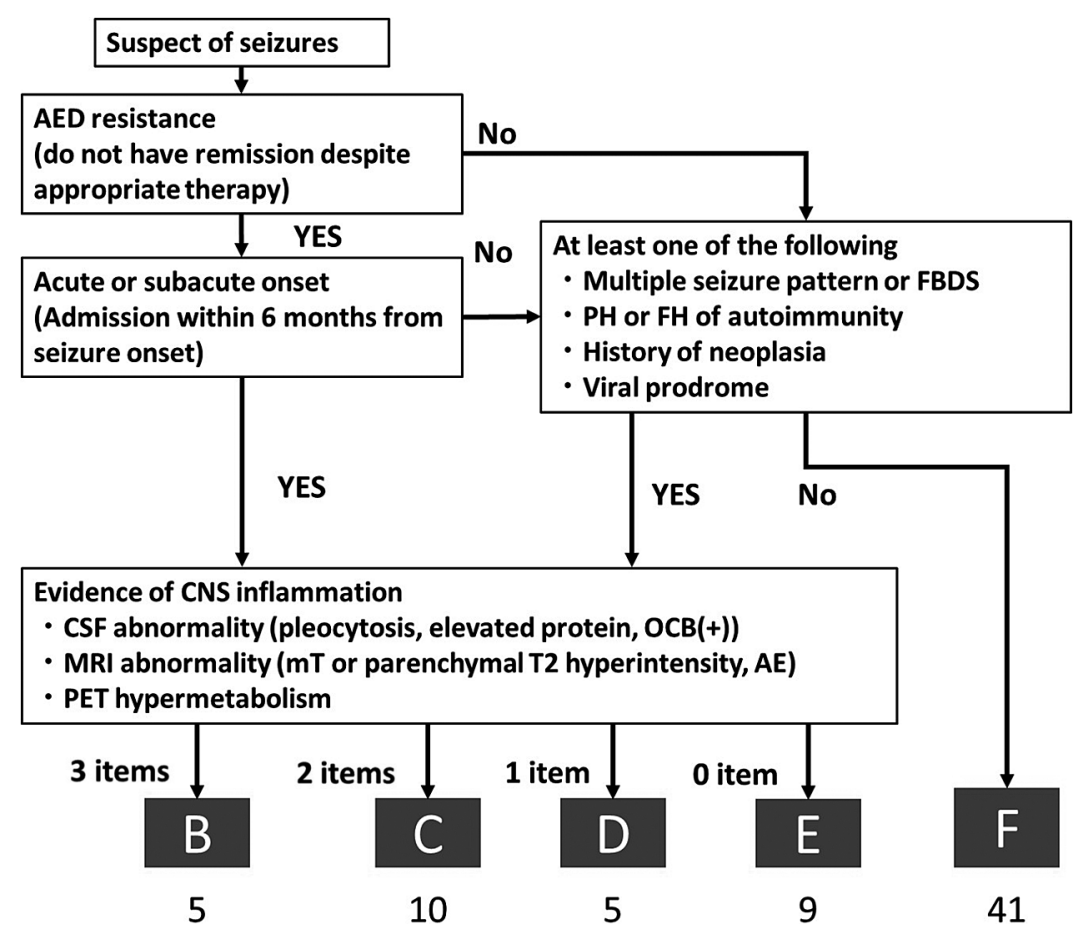

Fig. 2 Algorithm for diagnosis of autoimmune epilepsy without evaluation of neuronal antibody (proposal).

The numbers listed under each category represent the number of patients classified into their respective categories. AED: antiepileptic drugs, CSF: cerebrospinal fluid, FBDS: faciobrachial dystonic seizure, PH: past history, FH: family history, CNS: central nervous system, OCB: oligoclonal bands, mT: medial temporal, AE: amygdala enlargement.

目のみを D 群，いずれも満たさないものを $\mathrm{E}$ 群と分類した. また抗神経抗体の結果を考慮せずに，どの程度正確な診断 が可能かを評価するために，抗体の有無を加味しないアルゴ リズム（第 1 段階と第 3 段階のみ）も検討した（Fig. 2)。最 後に臨床症状には関係なく, 第 3 段階の検査所見の異常項目 数のみで抗神経抗体の有無との関連を検討した。

\section{結果}

アルゴリズムを適応した 70 例のうち女性は 35 例（50\%）， 発症年齢の中央值は 54 歳（範囲は 9 74 歳）であった。抗体 陽性例は 13 例で全体の $19 \%$ であった，MRI は全例で施行さ れたが，髄液検査は 66 例で，FDG-PETは 68 例で施行されて いた，抗神経抗体は抗 VGKC 複合体抗体が 40 例，抗 NMDAR 抗体が 32 例, 抗 GAD 抗体が 68 例で検索されていた (Table 1).

アルゴリズムを適応した結果， $\mathrm{A}$ 群 11 例 (16\%)， B 群 3 例 (4\%), C 群 5 例 (7\%), D 群 4 例 (6\%), E 群 6 例 (9\%), F 群 41 例 $(58 \%$ ）と分類された（Fig. 3A）。アルゴリズム第 一段階の病歴 / 臨床症状から考えて自己免疫性てんかんの可 能性が高く，追加検査を要すると判断された群 (A〜E 群) は 合計で 29 例であり，全体の約 4 割 $(41.4 \%)$ を占めた。一方, アルゴリズムの臨床症状からは自己免疫性てんかんの可能性 が低いと判断された群（F群）に2 例の抗神経抗体陽性患者 が分類された。

抗神経抗体の検査結果（第 2 段階）を考慮せずに，すなわ
Table 1 Patient demographics (clinical and laboratory data).

\begin{tabular}{lc}
\hline Patient demographics & \\
\hline Age at onset (year), median (range) & $54(9-74)$ \\
Time to admission (month), median (range) & $10.5(1-420)$ \\
$\quad$ Admission within 6 months (subacute) & $26(37 \%)$ \\
Female & $35(50 \%)$ \\
AED resistance & $46(66 \%)$ \\
Multiple seizure types or FBDS & $4(6 \%)$ \\
Personal or family history of autoimmunity & $9(13 \%)$ \\
Neoplasm or ovarian cyst & $6(9 \%)$ \\
CSF abnormality* & $29 / 66(44 \%)$ \\
MRI abnormality & $30(43 \%)$ \\
FDG-PET hypermetabolism* & $15 / 68(22 \%)$ \\
Neuronal antibodies (positive) & $13 / 70(19 \%)$ \\
VGKC complex* & $9 / 40(23 \%)$ \\
NMDAR* & $1 / 32(3 \%)$ \\
GAD* & $4 / 68(6 \%)$ \\
\hline
\end{tabular}

* denotes the examination where limited patients were recruited. Percentage was calculated from these limited patients. AED: antiepileptic drugs, FBDS: faciobrachial dystonic seizure, CSF: cerebrospinal fluid, FDG-PET: fluorodeoxy glucose-positron emission tomography, VGKC: voltage-gated potassium channels, NMDAR: N-methyl$\mathrm{D}$-aspartate receptor, GAD: glutamic acid decarboxylase. 
A

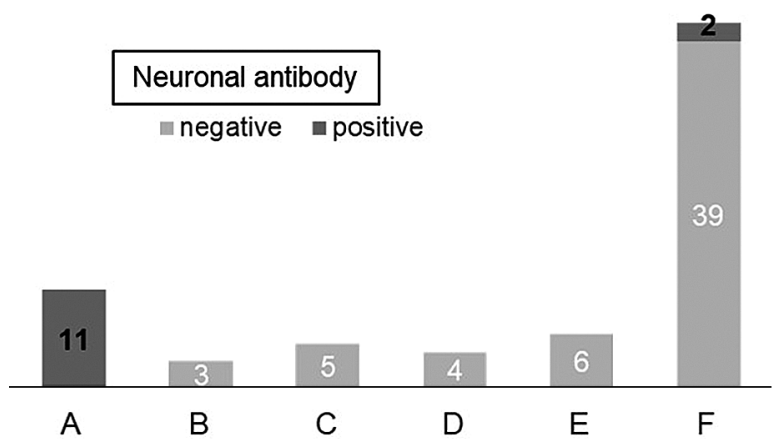

B

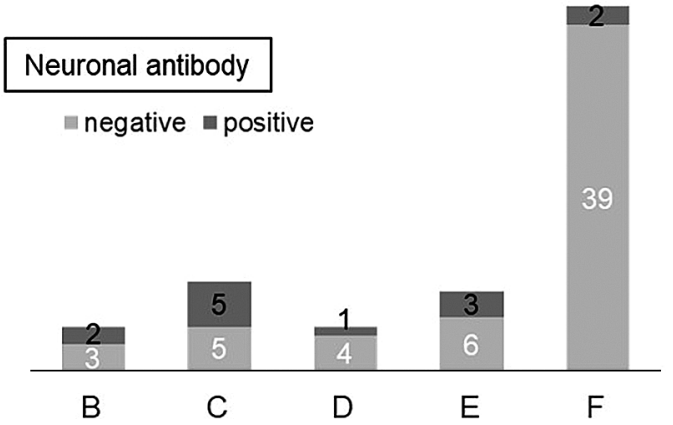

Fig. 3 Bar graph plot of the number of patients in each category. A: patients in each category (A-F) of the proposed algorithm (Fig. 1). $\mathrm{B}$ : patients in each category (B-F) of the proposed algorithm without considering the findings of neuronal antibody (Fig. 2). Eleven patients in Category A were incorporated into Category B-F according to the number of positive laboratory findings. Dark gray bar denotes patients with positive neuronal antibody findings, and light gray bar those with negative antibody findings. The figure in each bar denotes the number of patients.

ち第 1 段階（病歴/臨床症状）と第 3 段階（各種検査項目）か らなるアルゴリズムを適応した Fig. 2, この場合は A 群が存在 せず，BＥ群に抗神経抗体陽性例が割り振られる)。 B 群 5 例 $(7 \%), \mathrm{C}$ 群 10 例 $(14 \%), \mathrm{D}$ 群 5 例 $(7 \%), \mathrm{E}$ 群 9 例 (13\%) と分類された。笛のうち抗体陽性例は B 群 2 例，C 群 5 例， D 群 1 例， $\mathrm{E}$ 群 3 例であり，各群に㧍ける抗体陽性率 はB 群が $40 \%, \mathrm{C}$ 群 $50 \%$ ，D 群 $20 \%$ ， E 群 $33 \%$ であった (Fig. 3B).

次に, 病歴 / 臨床症状（第 1 段階）と抗神経抗体陽性（第 2 段階）を考慮せず，全対象患者で第 3 段階，すなわち各種 検查所見の異常項目数を検討した. 陽性検查項目数を 2 項目を カットオフ值として, 抗体陽性率を検討した。抗神経抗体陽性 は, カットオフ值以上の群 $(22$ 例 $)$ では 8 例，未満の群 $(48$ 例)では 5 例であり, カットオフ值以上の群で抗体陽性率が有 意に高かった（ $P=0.018$, Fisher の正確確率検定）（Table 2).
Table 2 2-by-2 table comparing positive antibody and laboratory findings.

\begin{tabular}{lcc}
\hline & $\begin{array}{c}\geq 2 \text { positive } \\
\text { lab findings }\end{array}$ & $\begin{array}{c}\leq 1 \text { positive } \\
\text { lab finding }\end{array}$ \\
\hline Ab positive & 8 & 5 \\
Ab negative & 14 & 43 \\
\hline$P=0.018$, Fisher's exact test. Ab: neuronal antibodies, lab: laboratory.
\end{tabular}

抗体陽性であるにもかかわらず F 群に分類された症例を示 す. 1 例目は 60 歳代男性で, 強直間代発作で発症し, その後 約 8 か月以上の経過で徐々に認知機能障害, 感情障害（易怒 性）が進行した ${ }^{18)}$. 本症例は抗てんかん薬単剂でてんかん発 作がコントロール可能であった, 経過も緩徐進行性であった ことから，アルゴリズムで満たすべき臨床的特徴は有しな かったが，精查の結果 VGKC 複合体抗体陽性 $(2,463 \mathrm{pM})$ で あった (Fig. 4). 本症例で特徴的な所見として, 長時間ビデオ 脳波モニタリングで, 診断時に両側側頭部に 48 時間で計 51 回の無症候性の発作パターンを認めたことが挙げられる. 2 例目は 30 歳代女性で, 難治性の経過から自己免疫性てん かんが疑われたが，それ以外の臨床的特徴は有しなかった。 抗 GAD 抗体陽性であったが, 抗 GAD 抗体関連の難治部分 てんかんや自己免疫性辺縁系脳炎としては力価が低かった （190 U/ml, Radioimmunoassay（RIA）法, カットオフ值を $100 \mathrm{U} / \mathrm{m} l$ とした $\left.{ }^{19)}\right)$.

\section{考察}

当院の患者群の後方視的解析で，今回提唱した診断アルゴ リズムが抗神経抗体の存在を予見する上で有用かどうかを検 討した。 アルゴリズムを用いることにより，所定の検査で 2 項目以上の異常がある場合に抗神経抗体の結果を待たずに 診断できる可能性が示唆された。

現在, 本邦では抗神経抗体の測定に難渋する現実があり ${ }^{20)}$, 確定診断でないとはいえ参考になる情報を提供できることは 重要であると考えられる。ただ，このアルゴリズムでは抗体 陽性の 13 例のうち大半（11 例）は臨床的特徵を有し第 2 段 階へ診断アルゴリズムを進めることができたが，2 例 (1 例が 抗 VGKC 複合体抗体陽性，1 例は低力価の抗 GAD 抗体陽性) ではアルゴリズム第 1 段階の病歴 / 臨床症状から自己免疫性 てんかんの可能性が低いと判断された，本アルゴリズムは自 己免疫性「てんかん」の診断アルゴリズムであり，自己免疫 性（辺縁系）脳炎でてんかん発作が前景に立たない症例（Fig. 4 の症例，臨床発作は1回のみ）は本アルゴリズムでは検出 されにくい点は注意を要する。また，特に抗 $\mathrm{GAD}$ 抗体に関 しては, 高力価群（数千～数万 $\mathrm{U} / \mathrm{ml}, \quad \mathrm{RIA}$ 法）では難治部分 てんかんや自己免疫性辺縁系脳炎患者に打いてその病的意義 は確立しているが ${ }^{19}$ ), 低力価群 ( 〜 数百 $\mathrm{U} / \mathrm{m} l$ ) では確立して 扮らず，その取扱いについては慎重に検討する必要がある。 今回の検討でも低力価群では Toledano らが示した自己免疫 


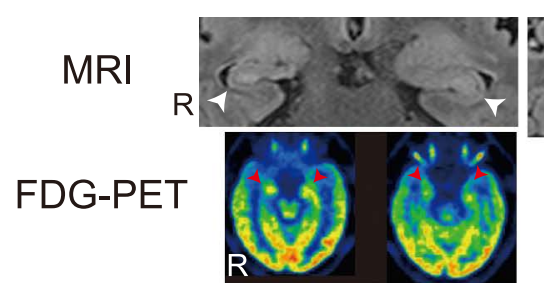

Subclinical EEG

vEEG
Clinical seizure
Memory impairment

Memory impairment

HDS-R

Irritability $\times 51 / 2$ nights

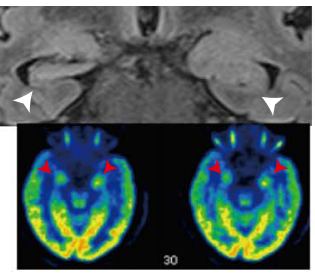

Subclinical EEG seizure pattern $x$ 10/2 nights

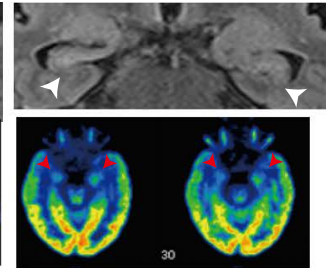

Subclinical EEG seizure pattern $x$ 10/2 nights
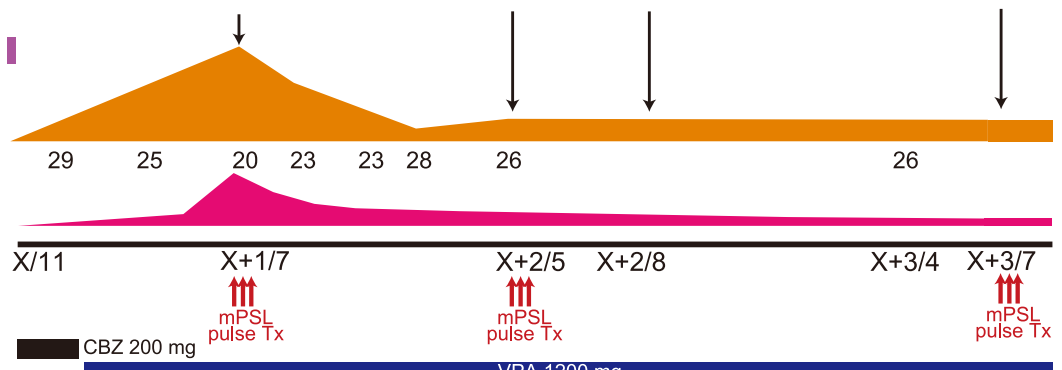

T3-T5 T5 -01 10

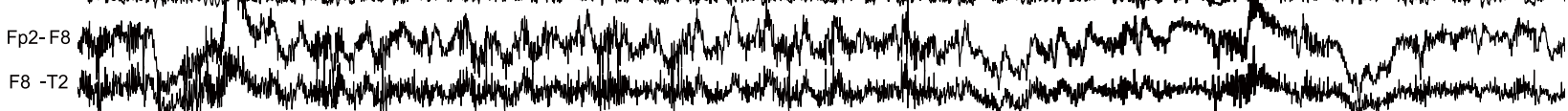
$T_{2}^{-T} 4$

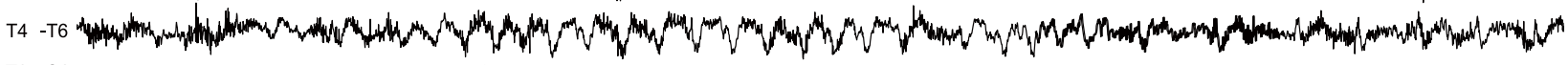

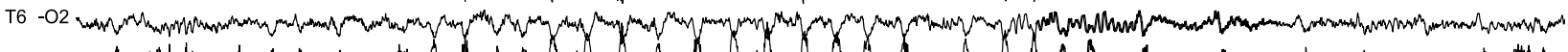

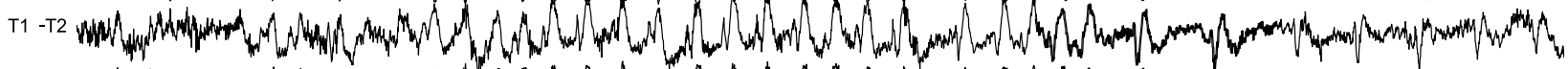

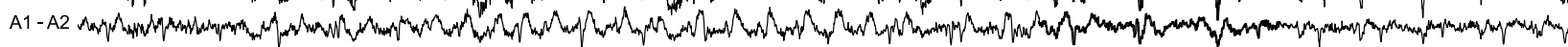

Fig. 4 Clinical course and EEG findings of the patient whom we could not diagnose by using the proposed algorithm.

EEG showed subclinical seizure patterns arising from the left or right temporal areas independently. Modified from ref (18) with permission. VGKC: voltage-gated potassium channels, Ab: neuronal antibody, vEEG: long-term Video/EEG monitoring, GTCS: generalized tonic-clonic seizure, HDS-R: Hasegawa dementia rating scale-revised, CBZ: Carbamazepine, VPA: Valproic acid, mPSL: Methylprednisolone.

性てんかんの臨床的特徴を満たしておらず F群に分類された ことから, 高力価の症例とは臨床像が異なることが推測される.

これまで自己免疫性てんかんにおいて, 臨床所見と抗神経 抗体陽性の関係について統計的に検討した研究は我々が調べ 得た限りないものの, 臨床症状と検査所見をスコア化して抗 神経抗体との関連について検討した研究は存在する。 Dubey $ら^{21)}$ は, 臨床症状として「新規発症の進行性の精神状態変 化, あるいは新規発症のてんかん発作」「精神興奮, 攻撃性, 感情不安定」「自律神経失調症状」「ウイルス先行感染」「顔面 ジスキネジアあるいは faciobrachial dystonic seizures (FBDS)」 $\lceil 2$ 剂以上の適切な抗てんかん薬による治療に抵抗性」「悪性 疾患の存在」を挙げ，また検査所見として「炎症を示唆する
髄液所見（髄液蛋白が $50 \mathrm{mg} / \mathrm{d} l$ より多いないし 5 cells $/ \mu l$ を 超える単核球増多)」「脳 MRI で辺縁系脳炎を示す信号変化」 を挙げており, 各項目に1〜2点のスコアをつけている. 最終 的に合計スコアが 4 点以上の患者群で, 抗神経抗体が陽性で あることと有意に相関したとしている。これは簡便であると いう点で有用であり，また「精神症状，感情障害の有無」に ついて検討しており, 辺縁系脳炎が前景に立つような症例に ついても見逃しを防ぐことができる可能性はある。しかし臨 床症状と検査所見を同列にして検討しており, 特に臨床検査 の各項目で高いスコアが割り当てられていることから, 髄液 検査などの検査結果が重要な基準と位置づけられている。し かし, このスコアリング法ではどのような症例で腰椎穿刺な 
どの侵襲的な検査を追加するべきかという観点での示唆は 得られない，それと比較して本アルゴリズムでは，まず第 1 段階で臨床症状と臨床経過で検討し, 追加検査が必要と判断 した症例についてさらに検査を進める方法をとって抢り，よ り実際の診断手順に則して㧍り実用的と考えられる。FDGPET は現時点では施行できる施設が限られ，検査できなかっ た場合は評価できる項目が減少することで診断の感度が下 がる可能性はある。しかし Graus らは自己免疫性辺縁系脳炎 に扔いて診断に有用である可能性を示唆しており ${ }^{16)}$ ，検査が 可能であれば自己免疫性てんかんの診断においても同様に有 用である可能性が高い. 脳血流シンチグラフィーについては, 一部で有用性が報告されて㧍り ${ }^{22}$ ，今後の症例の蓄積とアル ゴリズムの改訂が望まれる。

本研究の限界と今後の課題としては，下記の四つがあげら れる。一つ目は，抗体陽性例のうち 2 症例で，アルゴリズム の第 1 段階（臨床的特徵）で自己免疫性てんかんの可能性が 低いと判断され診断に至らなかった点である。原因としては 前述の通り「辺縁系脳炎」による精神症状・記銘力低下が前 景に立つ症例での見逃しが考えられる。この点に対する方策 としては，精神・神経症状の観察が有用であると考えられる。 また近年，自己免疫性辺縁系脳炎・てんかんを示唆する所見 として, 発作周辺期の自律神経症状と抗神経抗体との関連が 指摘されている. Baysal-Kirac ら ${ }^{23)}$ は長時間ビデオ脳波モ二 タリングで発作周辺期の自律神経症状が観察された 58 例の うち，17 例（29.3\%）で何らかの抗神経抗体が陽性であった と報告した。抗体陽性例では特に腹部症状（上腹部 aura，嘔 気)，立毛，発作時発熱，尿意ひっ迫，咳嗽といった症状との 関連が示唆された。また Rocamora ら ${ }^{24)}$ は，766 例の長時間 ビデオ脳波モニタリング検查を施行した難治性てんかん患者 の後方視的解析で，5例 (0.65\%) で立毛発作が主たる発作症 候であり，5例全例が側頭葉てんかんであったと報告してい る。病因は全例が辺縁系脳炎であり，3例が抗 leucine-rich glioma-inactivated 1 (LGI1) 抗体, 1 例が抗 $\mathrm{Hu}$ 抗体, 1 例が 抗 Ma2 抗体陽性であった。これらは発作周辺期の自律神経症 状と自己免疫性边縁系脳炎·てんかんとの関連を示しており， アルゴリズム第一段階への反映が今後の検討課題である.

二つ目は，本アルゴリズムでは，脳波所見について言及し ていない点である，Grausらは自己免疫性辺縁系脳炎の診断 基準に「両側側頭部のてんかん性放電あるいは徐波」を挙げ ている ${ }^{16)}$. Steriade らは，9例の抗 LGI1 抗体陽性脳炎患者の 長時間ビデオ脳波モニタリングにおいて，8例で発作が観察 され，さらにそのうち5例で subclinical seizure patternが見られ， いずれも側頭部に分布していたと報告した ${ }^{25}$. 前述の Fig. 4の 症例のように発作間欠期，および発作時いずれの脳波上の異 常所見も自己免疫性辺縁系脳炎・てんかんの診断に有用な可 能性があり，アルゴリズム（検查成績）への導入を検討する 必要がある。

三つ目としては，髄液異常の判定項目が挙げられる，本研 究では過去の自己免疫性辺縁系脳炎に関する文献 ${ }^{11)}$ を参考 に, 細胞数増多, 髄液蛋白上昇, OCB 陽性を判定項目とした。
OCB 陽性は中枢神経内の特異的な免疫応答を示すが, 現在標 的抗原が同定されている抗神経抗体は血清で検出できるもの が多く，その場合は抗体が血液脳関門（BBB）を超えて中枢 神経組織に影響を及ぼすと考えられる ${ }^{26)}$. スクリーニングと しては非特異的ではあるが IgG や IgG index が適切な可能性も あり，今後検証が望まれる。

最後に，すべての患者で既知の抗神経抗体すべてを測定で きていない点, 既知の抗神経抗体陰性の自己免疫性てんかん について検討できていない点が挙げられる。抗神経抗体は現 在多種多様な抗体が次々発見されており，Grausらは自己抗 体陰性だが自己免疫性脳炎が疑われる場合の診断基準も提起 している ${ }^{16)}$ ．自己免疫性てんかんの一部は自己免疫性脳炎の 不全型（軽症型）と考えられ，既知の自己抗体㓌性の自己免 疫性てんかんも存在しうる。実際，Toledano らは抗体陰性の 患者に免疫治療をして 6 例中 2 例で治療反応性が見られたと して扮り ${ }^{11)}$ ，これらも既知抗体陰性の自己免疫性てんかんと 考元られる. 最終的にはこれらの抗体除性患者も診断可能な アルゴリズムの作成が目標となる，本アルゴリズムでは， B， C を「抗体陰性の自己免疫性てんかんの可能性がある群」, D, $\mathrm{E} ， \mathrm{~F}$ を「自己免疫性てんかんの可能性が低い群」とすること で，抗体陰性群も含めた自己免疫性てんかんの診断に有用な 可能性が考えられる。 今後他の既知の抗神経抗体を含め網羅 的に抗神経抗体を測定した患者群で，本アルゴリズムの有用 性のさらなる検討が望まれる。

謝辞：各種神経抗体を測定してくださりましたOxford大学の Angela Vincent 先生（抗 VGKC 複合体抗体，抗 NMDA 受容体抗体)，金沢医 科大学総合医学研究所（現：新潟大学脎研究所）の田中惠子先生（抗 NMDA 受容体抗体)，鹿児島大学神経内科の渡邊修先生 (抗 VGKC 複 合体抗体)に深謝いたします，また，本論文をまとめるにあたり神経 免疫学の観点からご助言賜りました金沢医科大学神経内科の松井真 先生に深く抒礼を申し上げます。

利益相反: 京都大学大学院医学研究科てんかん・運動異常生理学 講座は, 寄附講座であり, 大塚製薬, グラクソスミスクライン, 日本 光電，UCB ジャパンの寄附金にて支援されている，京都大学大学院 医学研究科呼吸管理睡眠制御学講座は, 寄付講座であり, フクダ電子 株式会社, 帝人ファーマ株式会社, フジ・レスピロニクス株式会社, フイリップス・レスピロニクス合同会社, フクダライフテック関西株 式会社の寄付金にて支援されている。

\section{文献}

1) Graus F, Cordon-Cardo C, Posner JB. Neuronal antinuclear antibody in sensory neuronopathy from lung cancer. Neurology 1985;35:538-543.

2) Dalmau J, Furneaux HM, Rosenblum MK, et al. Detection of the anti-Hu antibody in specific regions of the nervous system and tumor from patients with paraneoplastic encephalomyelitis/ sensory neuronopathy. Neurology 1991;41:1757-1764.

3) Gultekin SH, Rosenfeld MR, Voltz R, et al. Paraneoplastic limbic encephalitis: neurological symptoms, immunological findings and tumour association in 50 patients. Brain 2000;123:1481-1494. 
4) Solimena M, Folli F, Denis-Donini S, et al. Autoantibodies to glutamic acid decarboxylase in a patient with stiff-man syndrome, epilepsy, and type I diabetes mellitus. N Engl J Med 1988; 318:1012-1020.

5) Dalmau J, Gleichman AJ, Hughes EG, et al. Anti-NMDAreceptor encephalitis: case series and analysis of the effects of antibodies. Lancet Neurol 2008;7:1091-1098.

6) Irani SR, Alexander S, Waters P, et al. Antibodies to Kv1 potassium channel-complex proteins leucine-rich, glioma inactivated 1 protein and contactin-associated protein- 2 in limbic encephalitis, Morvan's syndrome and acquired neuromyotonia. Brain 2010;133:2734-2748.

7) Lancaster E, Dalmau J. Neuronal autoantigens-pathogenesis, associated disorders and antibody testing. Nat Rev Neurol 2012; 8:380-390.

8) Bien CG, Scheffer IE. Autoantibodies and epilepsy. Epilepsia 2011;52:18-22.

9) Malter MP, Helmstaedter $\mathrm{C}$, Urbach $\mathrm{H}$, et al. Antibodies to glutamic acid decarboxylase define a form of limbic encephalitis. Ann Neurol 2010;67:470-478.

10) Quek AM, Britton JW, McKeon A, et al. Autoimmune epilepsy: clinical characteristics and response to immunotherapy. Arch Neurol 2012;69:582-593.

11) Toledano M, Britton JW, McKeon A, et al. Utility of an immunotherapy trial in evaluating patients with presumed autoimmune epilepsy. Neurology 2014;82:1578-1586.

12) 松本理器, 坂本光弘, 池田昭夫. てんかんと自己免疫. Brain Nerve 2017;69:1115-1124.

13) Levite M. Autoimmune epilepsy. Nat Immunol 2002;3:500-503.

14) Scheffer IE, Berkovic S, Capovilla G, et al. ILAE classification of the epilepsies: Position paper of the ILAE Commission for Classification and Terminology. Epilepsia 2017;58:512-521.

15）田中惠子．免疫とてんかん症候群. Epilepsy 2014;8:93-97.

16) Graus F, Titulaer MJ, Balu R, et al. A clinical approach to diagnosis of autoimmune encephalitis. Lancet Neurol 2016;15: 391-404.

17) Irani SR, Michell AW, Lang B, et al. Faciobrachial dystonic seizures precede Lgil antibody limbic encephalitis. Ann Neurol 2011;69:892-900.

18) Kanazawa K, Matsumoto R, Shimotake A, et al. Persistent frequent subclinical seizures and memory impairment after clinical remission in smoldering limbic encephalitis. Epileptic Disord 2014;16:312-317.

19）赤石哲也, 神 一敬, 加藤量広ら. 抗 glutamic acid decarboxylase 抗体に関連した側頭葉てんかん 4 例の臨床的特徵. 臨床神経 2015;55:804-809.

20）坂本光弘, 松本理器, 池田昭夫. 自己免疫介在性脳炎·脳症. 日本てんかん学会編. 稀少てんかんの診療指標. 東京: 診断 と治療社；2017. p. 146-149.

21) Dubey D, Alqallaf A, Hays R, et al. Neurological autoantibody prevalence in epilepsy of unknown etiology. JAMA Neurol 2017; 74:397-402.

22) Heine J, Prüss $H$, Bartsch $T$, et al. Imaging of autoimmune encephalitis-Relevance for clinical practice and hippocampal function. Neuroscience 2015;309:68-83.

23) Baysal-Kirac L, Tuzun E, Erdag E, et al. Neuronal autoantibodies in epilepsy patients with peri-ictal autonomic findings. J Neurol 2016;263:455-466.

24) Rocamora R, Becerra JL, Fossas P, et al. Pilomotor seizures: an autonomic semiology of limbic encephalitis? Seizure 2014;23: 670-673.

25) Steriade C, Mirsattari SM, Murray BJ, et al. Subclinical temporal EEG seizure pattern in LGI1-antibody-mediated encephalitis. Epilepsia 2016;57:e155-e160.

26) Vincent A, Bien CG, Irani SR, et al. Autoantibodies associated with diseases of the CNS: new developments and future challenges. Lancet Neurol 2011;10:759-772. 


\title{
Abstract
}

\section{Proposal of a diagnostic algorithm for autoimmune epilepsy: preliminary investigation of its utility}

\author{
Mitsuhiro Sakamoto, M.D. ${ }^{1)}$, Riki Matsumoto, M.D., Ph.D. ${ }^{1)}$, Jumpei Togawa, M.D. ${ }^{12)}$, \\ Yuichiro Hashi, M.D. ${ }^{13)}$, Hirofumi Takeyama, M.D. ${ }^{4)}$ Katsuya Kobayashi, M.D., Ph.D. ${ }^{1)}$, \\ Akihiro Shimotake, M.D., Ph.D. ${ }^{5)}$, Takayuki Kondo, M.D., Ph.D. ${ }^{3)}$, \\ Ryosuke Takahashi, M.D., Ph.D. ${ }^{1)}$ and Akio Ikeda, M.D., Ph.D. ${ }^{5)}$ \\ ${ }^{1)}$ Department of Neurology, Kyoto University Graduate School of Medicine \\ ${ }^{2)}$ Department of Neurology, National Hospital Organization Kyoto Medical Center \\ ${ }^{3}$ Department of Neurology, Kansai Medical University Medical Center \\ ${ }^{4)}$ Department of Respiratory Care and Sleep Control Medicine, Kyoto University Graduate School of Medicine \\ ${ }^{5)}$ Department of Epilepsy, Movement Disorders and Physiology Kyoto University Graduate School of Medicine
}

The epilepsy syndrome of autoimmune etiology, namely, autoimmune epilepsy has attracted attention in recent years, as was reflected in the new etiology of "immunity" in the Epilepsy Classification of the International League Against Epilepsy (2017). However, no specific tests other than neuronal antibodies have been established. We proposed a diagnostic algorithm for autoimmune epilepsy and preliminarily investigated its clinical utility. We applied this algorithm to 70 patients who were suspected as having autoimmune epilepsy from clinical symptoms and laboratory findings in our institute. At least one of the three neuronal antibodies (antibodies to N-methyl-D-aspartic acid receptor (NMDAR), glutamic acid decarboxylase (GAD), and voltage-gated potassium channels (VGKC) complex) was evaluated. In this twostep algorithm, the patients were initially screened by clinical features and then evaluated by laboratory findings (neuronal antibodies, cerebrospinal fluid (CSF), MRI, FDG-PET). The results of preliminary application of the algorithm are described. One of the three neuronal antibodies was positive in 13 patients. In this preliminary investigation, it was suggested that two or more abnormal findings in the diagnostic tests (CSF, MRI, FDG-PET) favors the diagnosis of autoimmune epilepsy. On the other hand, two patients with a positive neuronal antibody test failed the first step (clinical features), partly because epilepsy was not the major manifestation of autoimmune encephalitis (VGKC complex antibody) or due to a relatively low titer of the antibody (GAD antibody). Recruitment of the patient cohort with comprehensive neuronal antibody testing and multivariate analysis of laboratory findings is warranted for validation and modification of the proposed algorithm.

(Rinsho Shinkeigaku (Clin Neurol) 2018;58:609-616)

Key words: autoimmune encephalitis, epilepsy, early diagnosis, algorithm 